\title{
Manganese N-Heterocyclic Carbene Pincers for the Electrocatalytic Reduction of Carbon Dioxide
}

\author{
Tessa H. T. Myren, ${ }^{\dagger \neq}$ Alyssia M. Lilio, ${ }^{\dagger \neq}$ Chloe G. Huntzinger,,$^{\dagger}$ Jonathan W. Horstman, ${ }^{\dagger}$ Taylor A. Stinson, ${ }^{\dagger}$ \\ Trevor Franklin, ${ }^{\dagger}$ Curtis Moore, ${ }^{*}$ Bimala Lama, ${ }^{\dagger}$ Hans H. Funke, ${ }^{a}$ Oana R. Luca ${ }^{\dagger *}$ \\ 'Department of Chemistry and Biochemistry, 215 UCB., University of Colorado Boulder, Boulder CO, 80300 USA \\ Department of Chemistry and Biochemistry, University of California San Diego, 9500 Gilman Dr., MC 0358, La Jolla CA 92093 - \\ 0358 \\ ${ }^{a}$ Department of Chemical and Biological Engineering, 596 UCB, University of Colorado Boulder, Boulder CO, 80300 USA \\ Fax: (+)1 3037396721 \\ *E-mail: oana.luca@colorado.edu
}

\section{Table of Contents}

1. Description of Diffusion Ordered Spectroscopy NMR Experiments

2. Electrochemical Experiments

3. Controlled Potential Electrolysis and Headspace Analysis

4. Infrared Spectroscopy

5. Crystal Structure Details for 1

6. Comparison of $i_{c a t} / i_{p}$ for 1 and 2 against several known $\mathrm{CO}_{2}$ reduction catalysts from literature values and measured in our hands for side-by-side comparison 


\section{Description of Diffusion Ordered Spectroscopy NMR experiments}

All spectra were acquired on an Agilent INOVA 500 spectrometer with VNMRJ 3.2 software operating at $499.599 \mathrm{MHz}$ equipped with a $5 \mathrm{~mm}$ triple resonance $\mathrm{HCN}$ Agilent probe at $295 \mathrm{~K}$ on $500 \mu \mathrm{L}$ samples at $22^{\circ} \mathrm{C}$. A $5 / 3 \mathrm{~mm}$ Precision NMR sample glass tube from Wilmad was used to avoid convection. The following are the parameters for the ${ }^{1} \mathrm{HNMR}$ data acquisition: acquisition time $3.0 \mathrm{~s}$, spectral width $8 \mathrm{KHz}$, pulse width 6.12 $\mu \mathrm{s}$, relaxation delay $2.0 \mathrm{~s}$, and no. of scans 16 . For the 2D DOSY NMR experiment, a gradient compensated stimulated DOSY (DgcsteSL_cc) pulse sequence was used with spectral width $5 \mathrm{kHz}$, relaxation time $30 \mathrm{~s}\left(5 \mathrm{xT}_{1}\right)$ and 16 scans. The duration of the magnetic field pulse gradients $(\delta)$ was optimized for each diffusion time $(\mathrm{t})$ in order to obtain $5-10 \%$ residual signal with maximum gradient strength. A pulse field gradient length (gt1) of 2 $\mathrm{ms}$ and a diffusion delay $(\delta)$ of $40 \mathrm{~ms}$ were used, and a series of 30 spectra on $32 \mathrm{~K}$ data points were collected with pulse gradients (g) increasing from 8.8 to $48 \mathrm{G} \mathrm{cm}-1$ in a linear ramp. All data were processed using Mnova software using the "peak heights" fit. After a two-dimensional Fourier transformation in magnitude mode, the DOSY dimension was reconstructed on a logarithmic scale using a mono-exponential fit to all resonances, and the peaks were reconstructed in the diffusion constant dimension on a grid of 128 data points. DOSY spectra are presented with chemical shifts (expressed in ppm) on the horizontal axis and diffusion coefficients on the vertical axis (expressed in $\mathrm{cm}^{2} / \mathrm{s}$ ). 


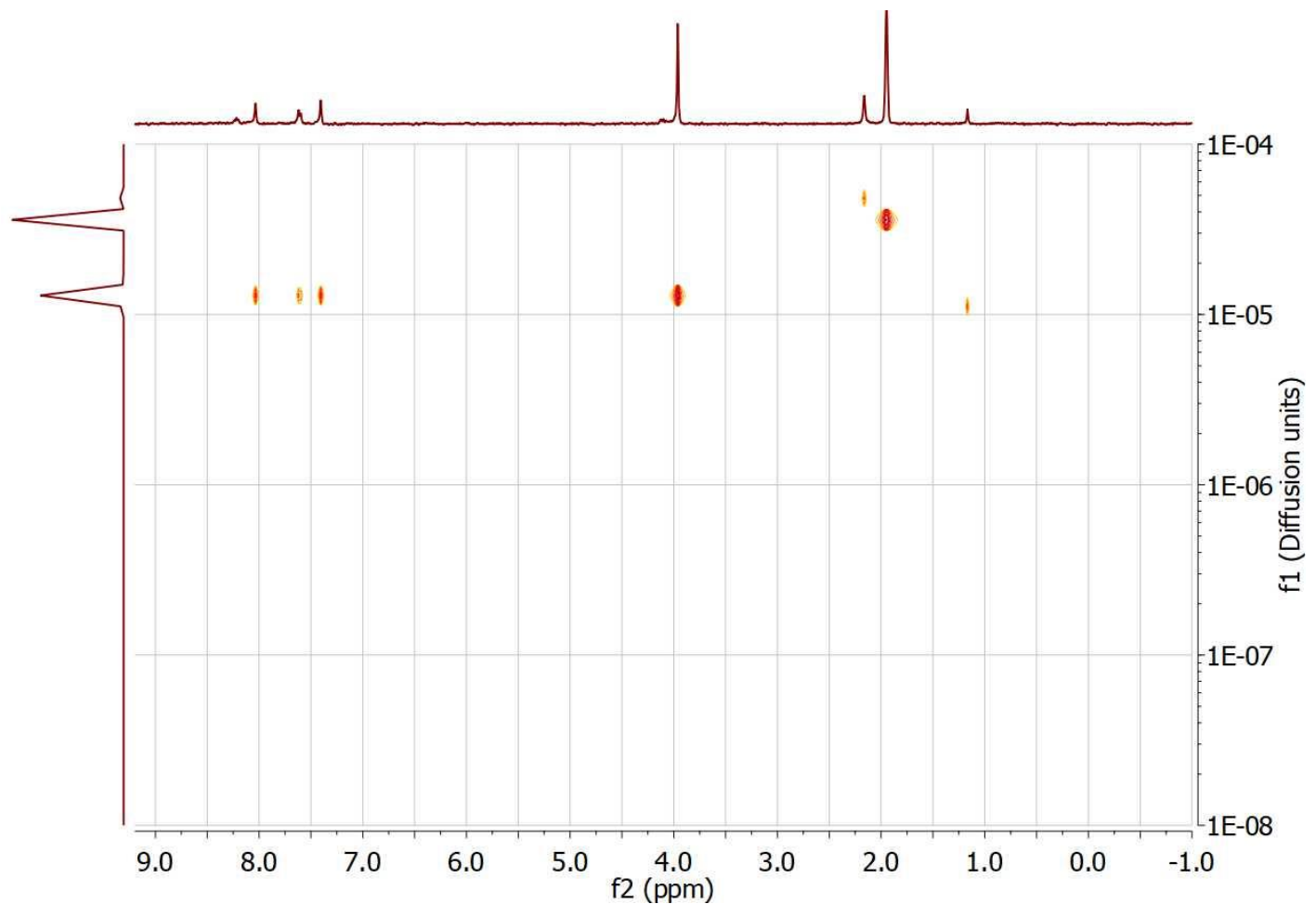

Figure S1. DOSY NMR spectra of 1 in Acetonitrile- $d_{3}$.

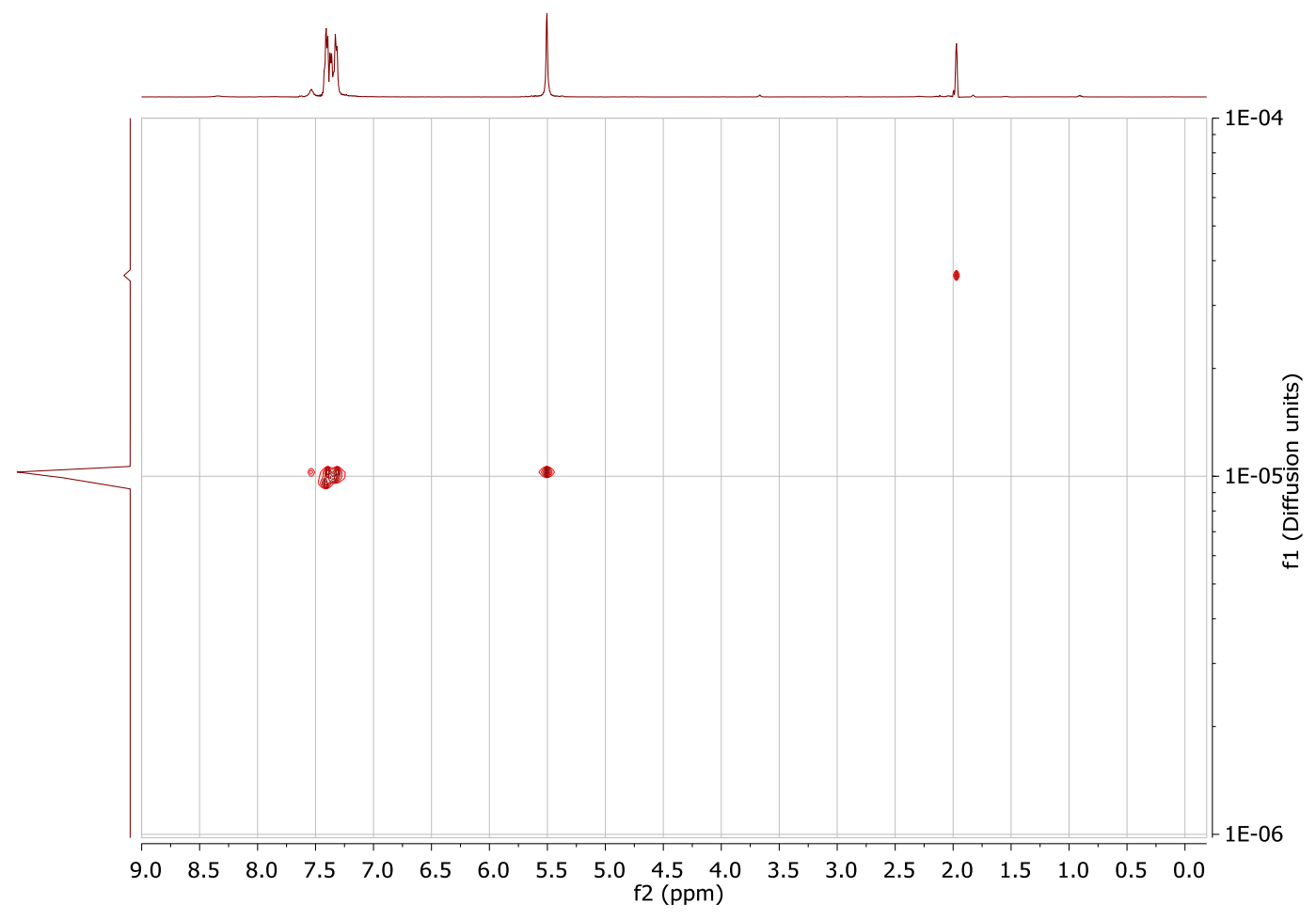

Figure S2. DOSY NMR spectra of 2 in Acetonitrile- $d_{3}$. 


\section{Electrochemical Experiments}

Cyclic Voltammograms (CVs) and Normal Pulse Voltammograms (NPV) in acetonitrile with $0.1 \mathrm{M} \mathrm{NBu}_{4} \mathrm{PF}_{6}(\mathrm{TBAH})$ were collected using a glassy carbon working electrode (3 $\mathrm{mm}$ diameter from Bioanalytical Systems) with a platinum wire counter electrode and a silver wire single junction pseudo-reference electrode (against ferrocene as external standard). CV and NPV measurements were recorded after rigorous exclusion of air via argon purge. Concentrations for argon-purged solutions used in the calculations for the number of electrons were adjusted to account for evaporated solvent. Data workup was performed on OriginPro vb9.4.0.220.

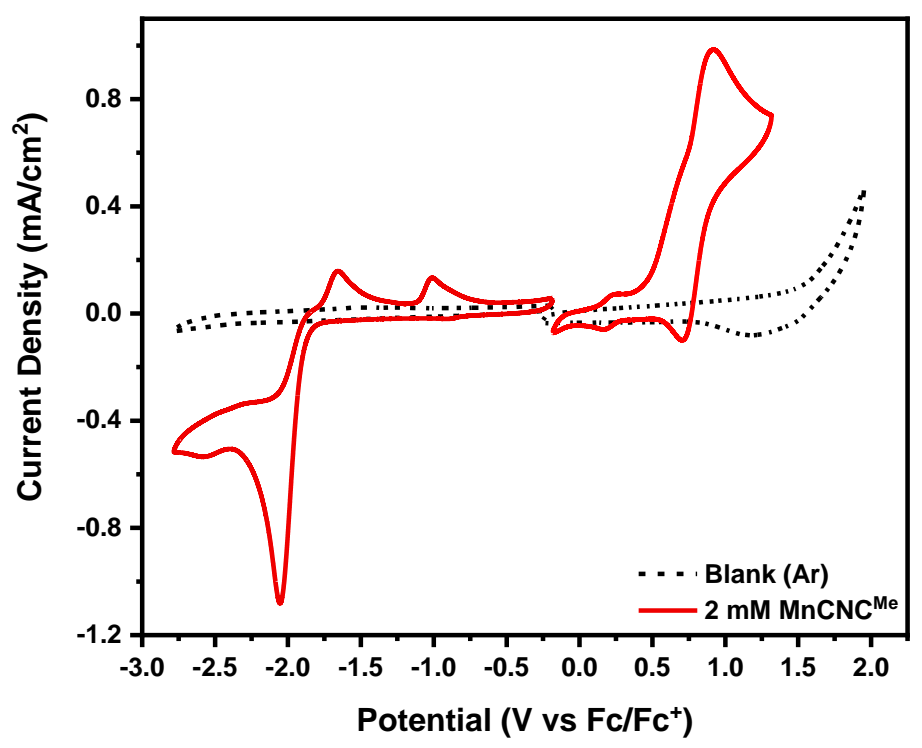

Figure S3. Cyclic voltammogram of $2 \mathrm{mM} 1\left(\mathrm{MnCNC}^{\mathrm{Me}}\right)$ solution in $0.1 \mathrm{M} \mathrm{NBu}_{4} \mathrm{PF}_{6}$ in acetonitrile. 


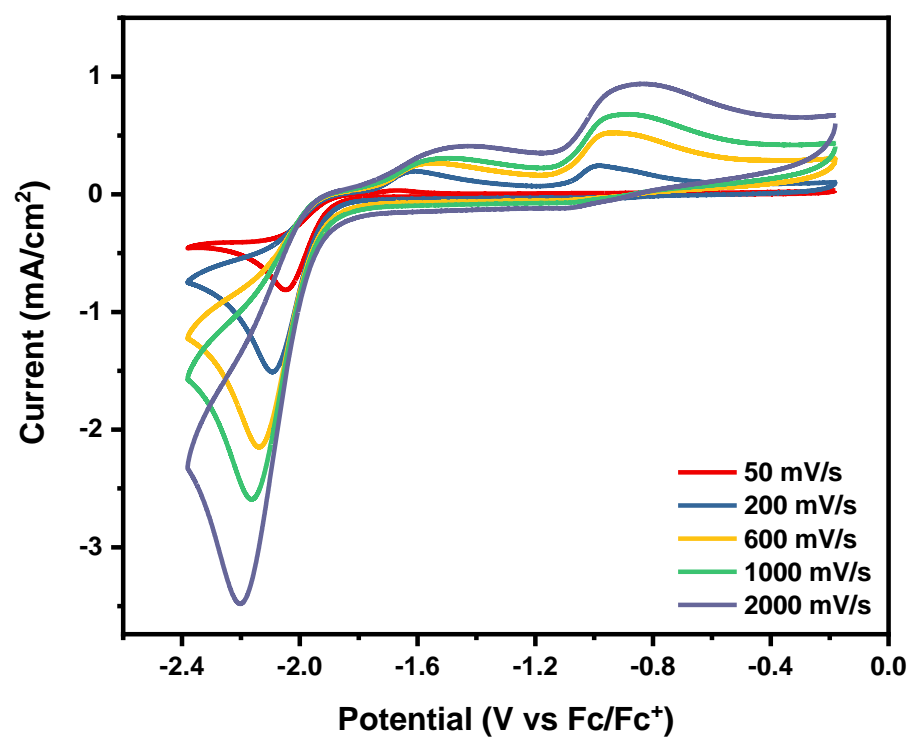

Figure S4. $2 \mathrm{mM} 1\left(\mathrm{MnCNC}^{\mathrm{Me}}\right)$ solution in $0.1 \mathrm{M} \mathrm{NBu}_{4} \mathrm{PF}_{6}$ in acetonitrile: overlay of reductive cyclic voltammograms at scan rate dependence at $50 \mathrm{mV} / \mathrm{s}(\mathrm{red}), 200 \mathrm{mV} / \mathrm{s}$ (blue), $600 \mathrm{mV} / \mathrm{s}$ (yellow), $1000 \mathrm{mV} / \mathrm{s}$ (green), $2000 \mathrm{mV} / \mathrm{s}$ (purple).

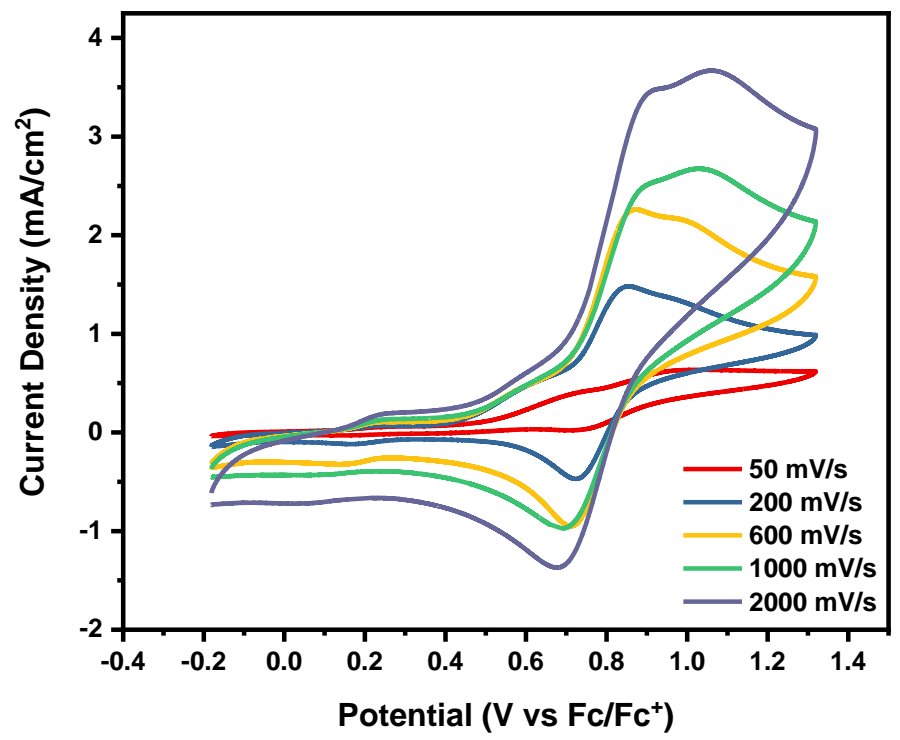

Figure S5. $2 \mathrm{mM} 1\left(\mathrm{MnCNC}^{\mathrm{Me}}\right)$ solution in $0.1 \mathrm{M} \mathrm{NBu}_{4} \mathrm{PF}_{6}$ in acetonitrile: overlay of oxidative cyclic voltammograms at scan rate dependence at $50 \mathrm{mV} / \mathrm{s}(\mathrm{red}), 200 \mathrm{mV} / \mathrm{s}$ (blue), $600 \mathrm{mV} / \mathrm{s}$ (yellow), $1000 \mathrm{mV} / \mathrm{s}$ (green), $2000 \mathrm{mV} / \mathrm{s}$ (purple). 

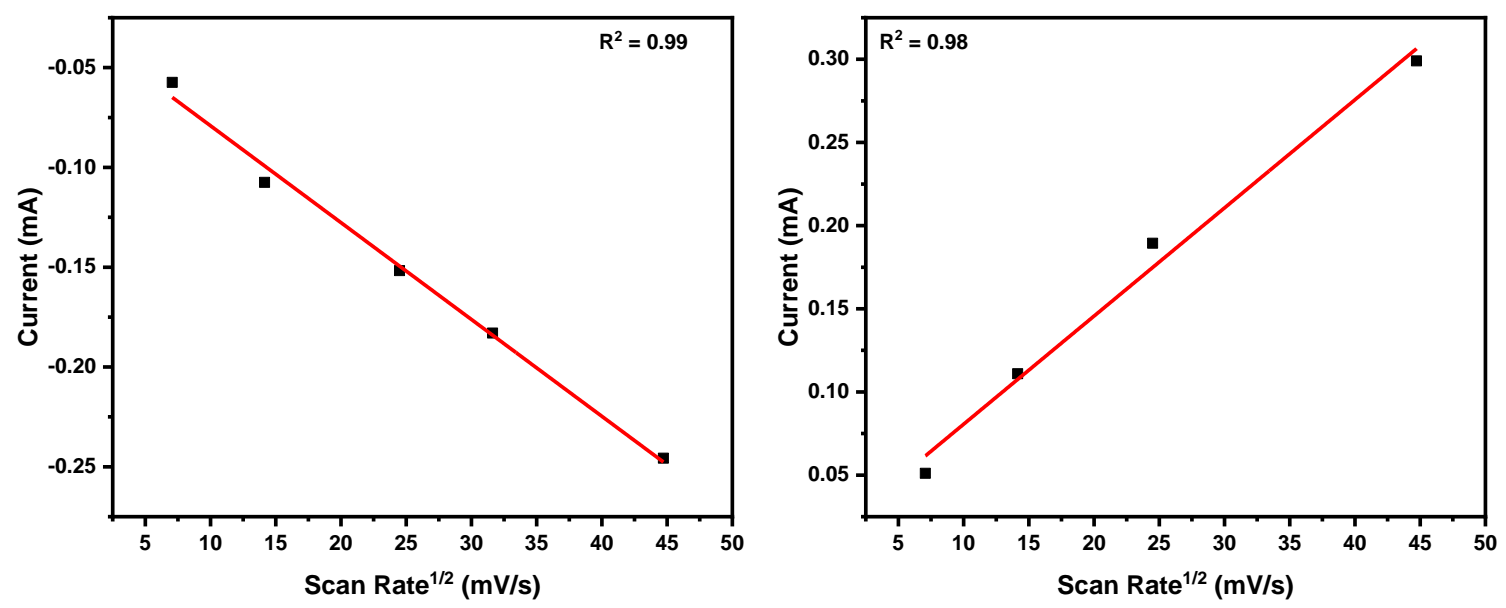

Figure S6. $2 \mathrm{mM} 1\left(\mathrm{MnCNC}^{\mathrm{Me}}\right)$ solution in $0.1 \mathrm{M} \mathrm{NBu}_{4} \mathrm{PF}_{6}$ in acetonitrile: Plot of maximum current of the major oxidative and reductive peaks at $1 /$ sqrt scanrate for scanrates of 50, 200, 600, 1000, and $2000 \mathrm{mV} / \mathrm{s}$.

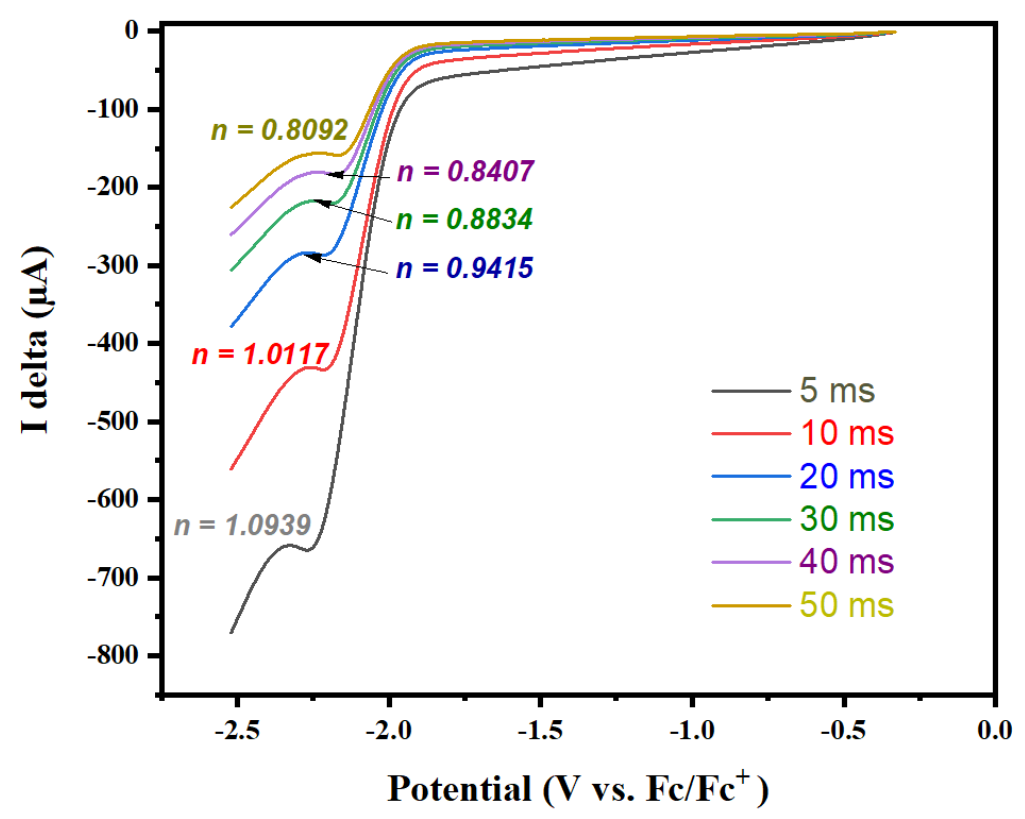

Figure S7. Normal pulse voltammogram of $3 \mathrm{mM} 1\left(\mathbf{M n C N C}^{\mathrm{Me}}\right)$ solution in $0.1 \mathrm{M}$ $\mathrm{NBu}_{4} \mathrm{PF}_{6}$ in acetonitrile at $5 \mathrm{~ms}$ (gray), $10 \mathrm{~ms}$ (red), $20 \mathrm{~ms}$ (blue), $30 \mathrm{~ms}$ (green), 40 ms(purple), $50 \mathrm{~ms}$ (yellow) wait time between pulses. 


\begin{tabular}{|c|c|c|c|}
\hline & Compound 1 & Compound 1 & Compound 1 \\
$\mathbf{I}(\mathbf{m i c r o a m p s})$ & 658.8 & 430.86 & 154.1 \\
$\mathbf{F}(\mathbf{C} / \mathbf{m o l})$ & 96485 & 96485 & 96485 \\
$\mathbf{A}\left(\mathbf{c m}^{\mathbf{2}}\right)$ & 0.070686 & 0.070686 & 0.070686 \\
$\mathbf{D}\left(\mathbf{c m}^{\mathbf{2} / \mathbf{s})}\right.$ & 0.000013 & 0.000013 & 0.000013 \\
$\mathbf{D}^{\mathbf{1 / 2}}$ & 0.003606 & 0.003606 & 0.003606 \\
$\mathbf{C}(\mathbf{m M})$ & 3.06946 & 3.06946 & 3.06946 \\
$\mathbf{p i}$ & 3.14159 & 3.14159 & 3.14159 \\
$\mathbf{p i} \mathbf{1}^{1 / 2}$ & 1.77245 & 1.77245 & 1.77245 \\
$\mathbf{t}(\mathbf{s})$ & $\mathbf{0 . 0 0 5}$ & $\mathbf{0 . 0 1}$ & $\mathbf{0 . 0 5}$ \\
$\mathbf{t}^{\mathbf{1} / \mathbf{2}}$ & 0.07071 & 0.10000 & 0.22361 \\
& & & \\
\hline $\mathbf{n}$ & $\mathbf{1 . 0 9 3 9}$ & $\mathbf{1 . 0 1 1 8}$ & $\mathbf{0 . 8 0 9 2}$ \\
\hline
\end{tabular}

Table S1-1. Sample data calculations used in the combined normal pulse voltammetry and diffusion-ordered spectroscopy method to determine number of electrons for the first reduction wave of $\mathbf{1}\left(\mathbf{M n C N C}^{\mathrm{Me}}\right)$. Data shown in Figure S7.

\begin{tabular}{|c|c|}
\hline $\mathbf{I}(\mathbf{m i c r o a m p s})$ & Compound 2 \\
$\mathbf{F}(\mathbf{C} / \mathbf{m o l})$ & 96485 \\
$\mathbf{A}\left(\mathbf{c m}^{2}\right)$ & 0.070686 \\
$\mathbf{D}\left(\mathbf{c m}^{2} / \mathbf{s}\right)$ & 0.000011 \\
$\mathbf{D}^{\mathbf{1 / 2}}$ & 0.003317 \\
$\mathbf{C}(\mathbf{m M})$ & 4.82633 \\
$\mathbf{p i}$ & 3.14159 \\
$\mathbf{p i}{ }^{1 / 2}$ & 1.77245 \\
$\mathbf{t}(\mathbf{s})$ & 0.05 \\
$\mathbf{t}^{\mathbf{1} / \mathbf{2}}$ & 0.22361 \\
& \\
\hline $\mathbf{n}$ & $\mathbf{1 . 1 2 3 2}$ \\
\hline
\end{tabular}

Table S1-2. Compiled data for calculation used in the combined normal pulse voltammetry and diffusion-ordered spectroscopy method to determine number of electrons for the first reduction wave of $\mathbf{2}\left(\mathrm{MnCNC}^{\mathrm{Bn}}\right)$. 


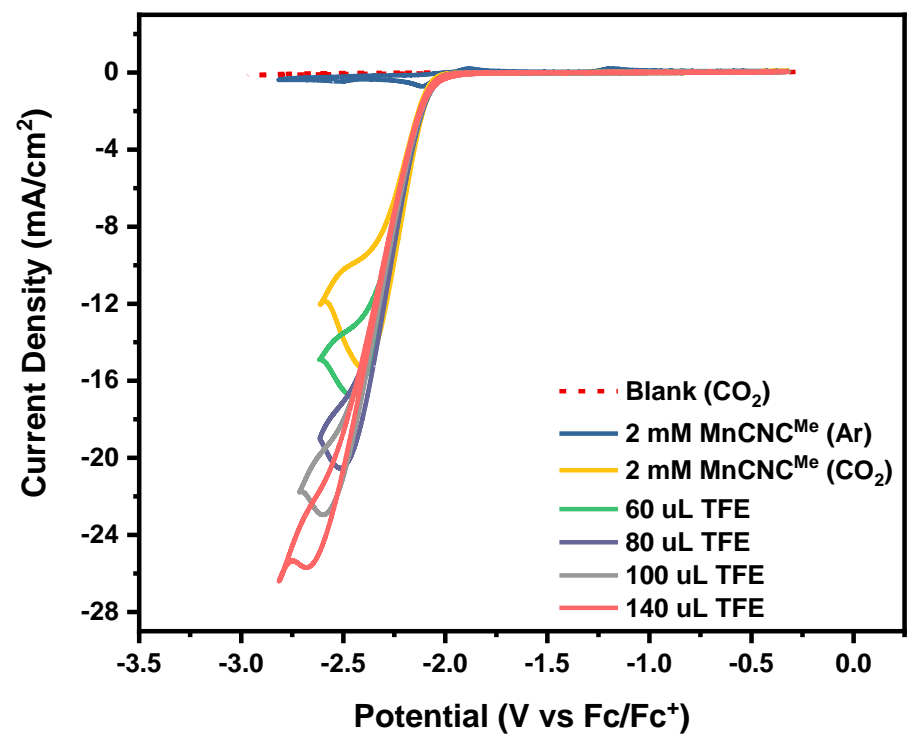

Figure S8. $2 \mathrm{mM} 1\left(\mathrm{MnCNC}^{\mathrm{Me}}\right)$ solution in $0.1 \mathrm{M} \mathrm{NBu}_{4} \mathrm{PF}_{6}$ in acetonitrile under an argon and $\mathrm{CO}_{2}$ atmosphere with increasing amounts of trifluoroethanol.

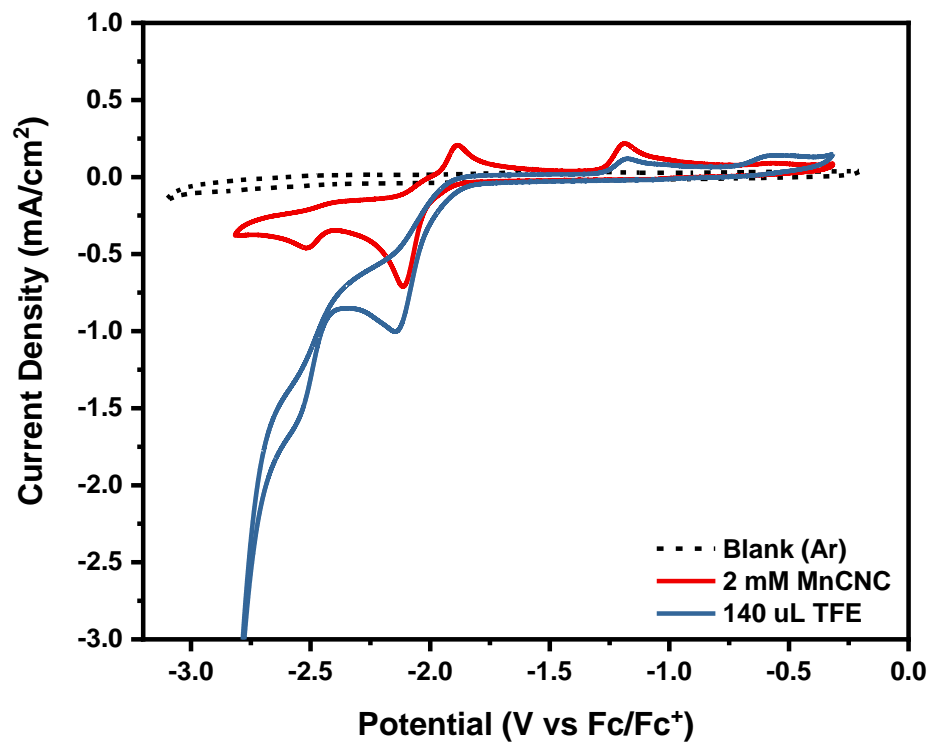

Figure S9. $2 \mathrm{mM} 1\left(\mathrm{MnCNC}^{\mathrm{Me}}\right)$ solution in $0.1 \mathrm{M} \mathrm{NBu}_{4} \mathrm{PF}_{6}$ in acetonitrile under an argon atmosphere with excess trifluoroethanol. 


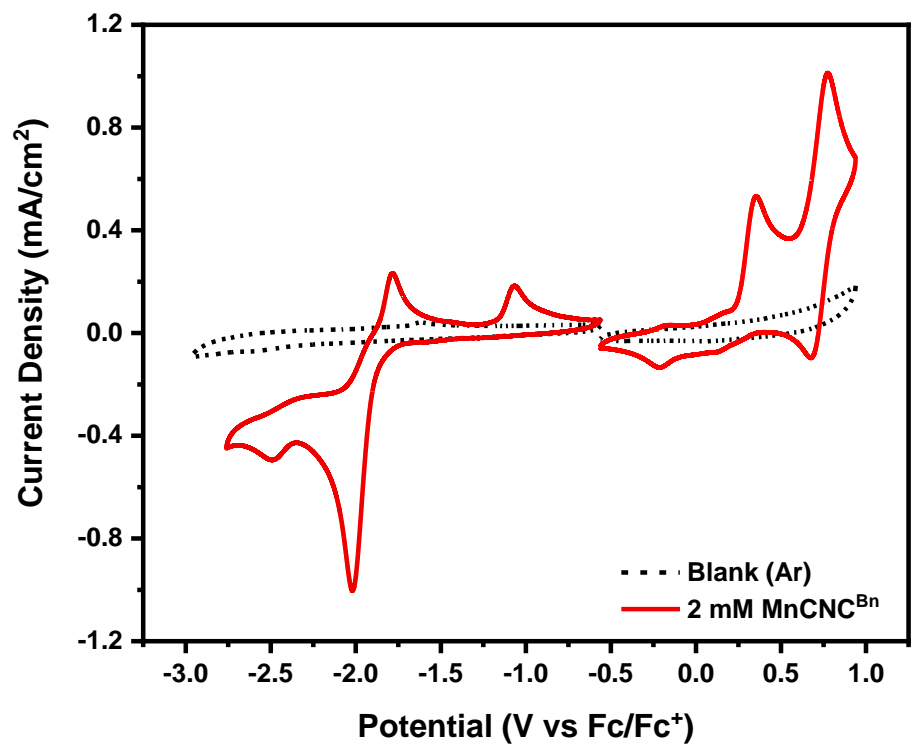

Figure S10. Cyclic voltammogram of $2 \mathrm{mM} 2\left(\mathrm{MnCNC}^{\mathrm{Bn}}\right)$ solution in $0.1 \mathrm{M} \mathrm{NBu} 4 \mathrm{PF}_{6}$ in acetonitrile.

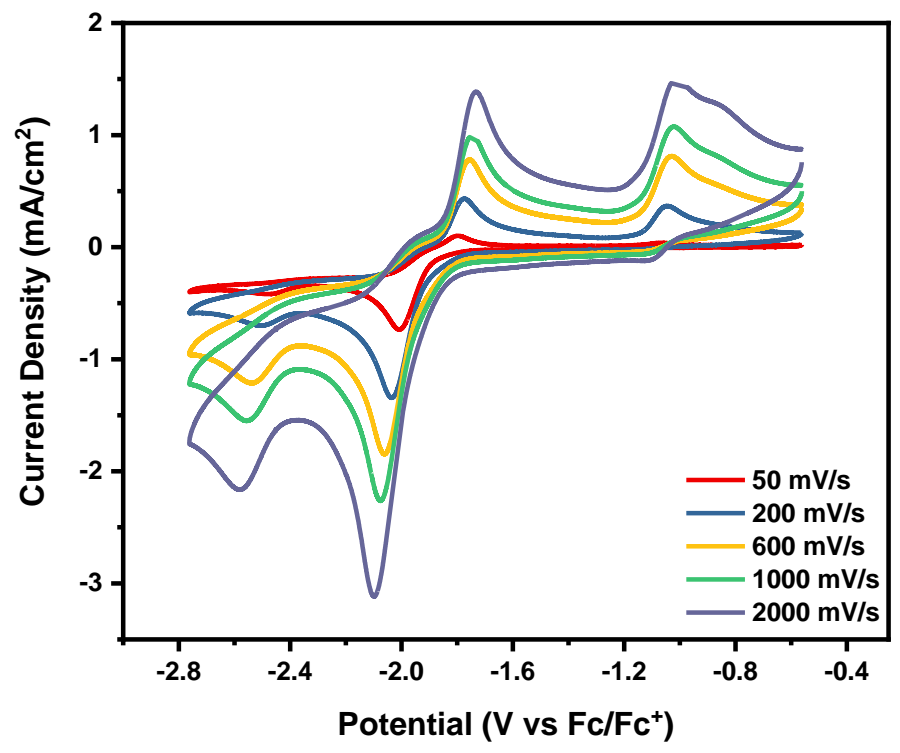

Figure S11. 2 mM $2\left(\mathrm{MnCNC}^{\mathrm{Bn}}\right)$ solution in $0.1 \mathrm{M} \mathrm{NBu}_{4} \mathrm{PF}_{6}$ in acetonitrile: overlay of reductive cyclic voltammograms at scan rate dependence at $50 \mathrm{mV} / \mathrm{s}$ (red), $200 \mathrm{mV} / \mathrm{s}$ (blue), $600 \mathrm{mV} / \mathrm{s}$ (yellow), $1000 \mathrm{mV} / \mathrm{s}$ (green), $2000 \mathrm{mV} / \mathrm{s}$ (purple). 


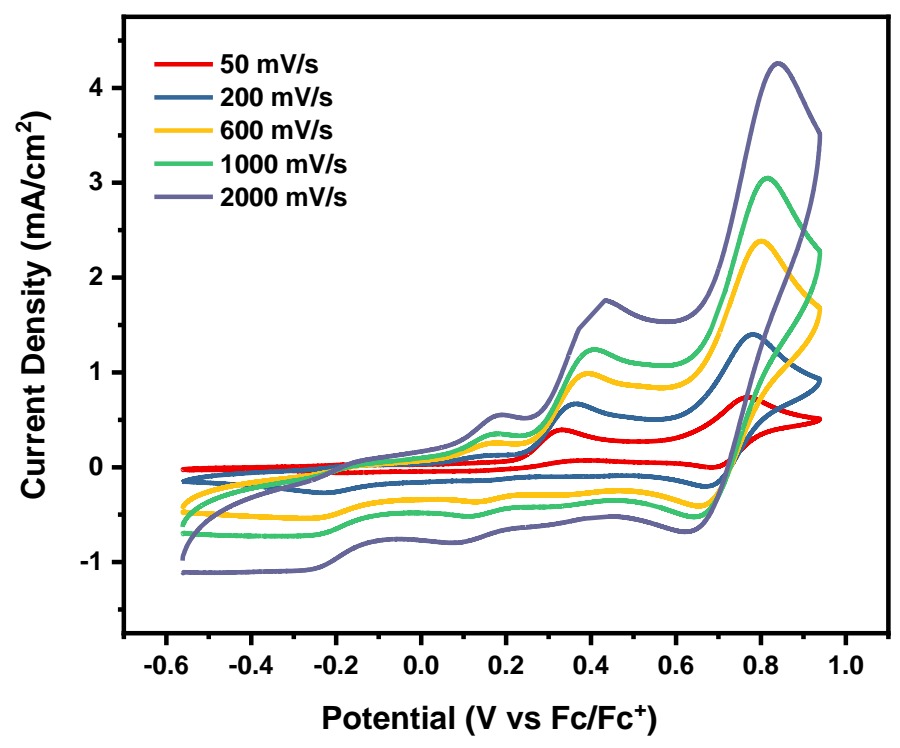

Figure S12. 2 mM 2 (MnCNC ${ }^{\mathrm{Bn}}$ ) solution in $0.1 \mathrm{M} \mathrm{NBu}_{4} \mathrm{PF}_{6}$ in acetonitrile: overlay of oxidative cyclic voltammograms at scan rate dependence at $50 \mathrm{mV} / \mathrm{s}$ (red), $200 \mathrm{mV} / \mathrm{s}$ (blue), $600 \mathrm{mV} / \mathrm{s}$ (yellow), $1000 \mathrm{mV} / \mathrm{s}$ (green), $2000 \mathrm{mV} / \mathrm{s}$ (purple).
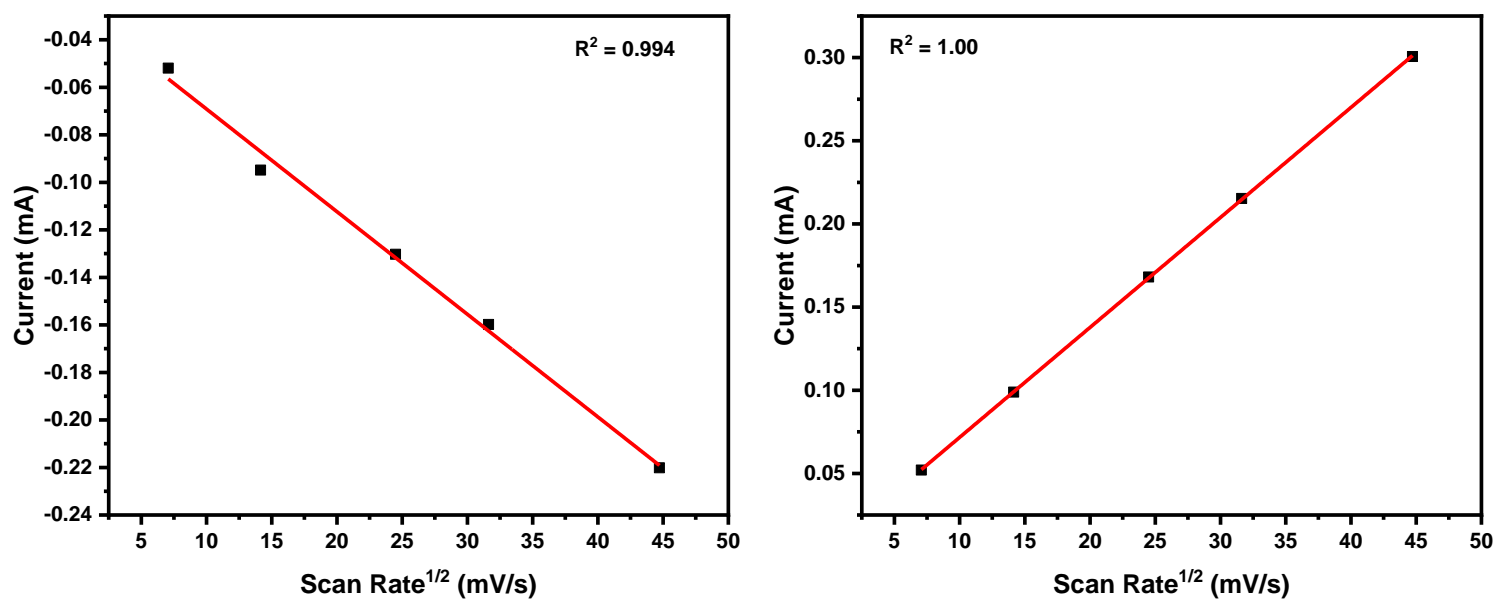

Figure S13. $2 \mathrm{mM} 2\left(\mathrm{MnCNC}^{\mathrm{Bn}}\right)$ solution in $0.1 \mathrm{M} \mathrm{NBu} 4 \mathrm{PF}_{6}$ in acetonitrile: Plot of maximum current of the major oxidative and reductive at $1 /$ sqrt scan rate for scan rates of $50,200,600,300,1000$, and $2000 \mathrm{mV} / \mathrm{s}$. 


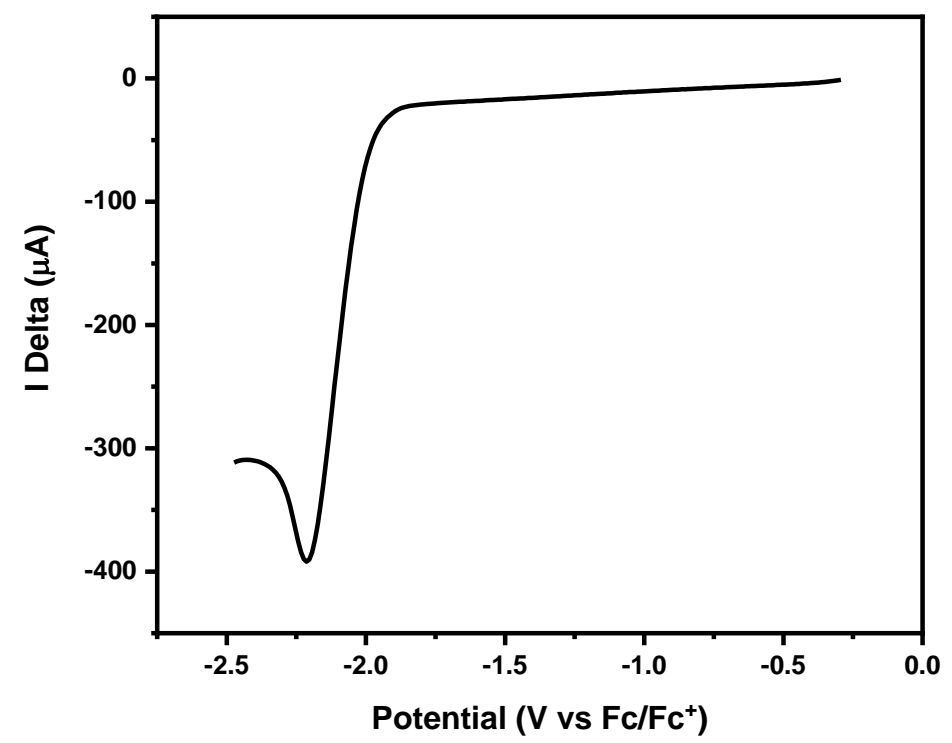

Figure S14. Normal pulse voltammogram of $5 \mathrm{mM} 2$ (MnCNC $^{\mathrm{Bn}}$ ) solution in $0.1 \mathrm{M}$ $\mathrm{NBu}_{4} \mathrm{PF}_{6}$ in acetonitrile.

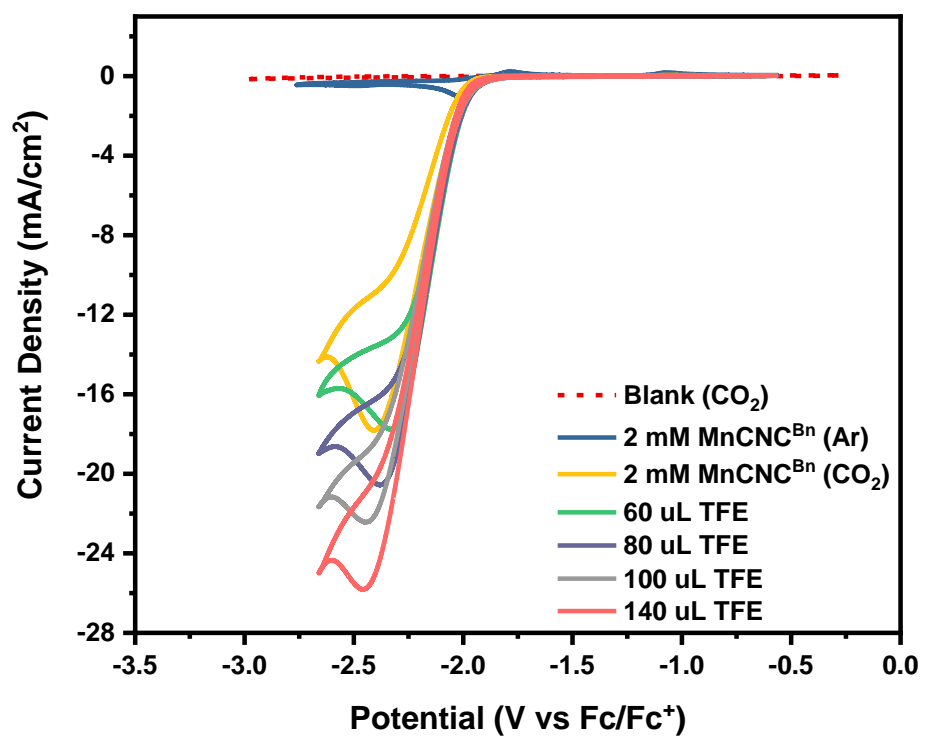

Figure S15. $2 \mathrm{mM} 2\left(\mathrm{MnCNC}^{\mathrm{Bn}}\right)$ solution in $0.1 \mathrm{M} \mathrm{NBu}_{4} \mathrm{PF}_{6}$ in acetonitrile under an $\operatorname{argon}$ and $\mathrm{CO}_{2}$ atmosphere with increasing amounts of trifluoroethanol. 


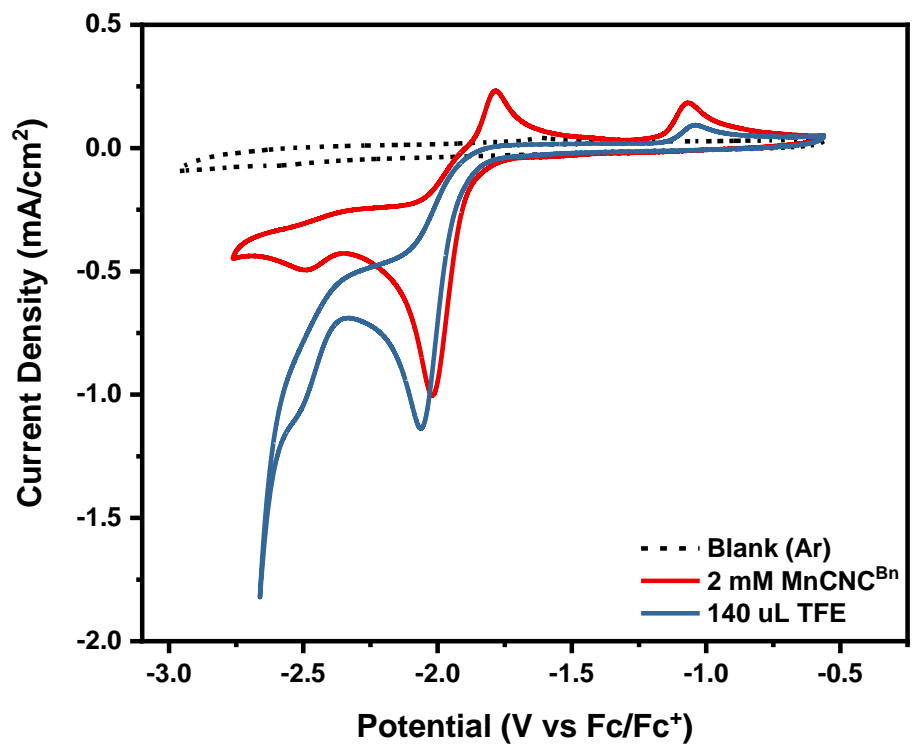

Figure S16. $2 \mathrm{mM} 2\left(\mathrm{MnCNC}^{\mathrm{Bn}}\right)$ solution in $0.1 \mathrm{M} \mathrm{NBu}_{4} \mathrm{PF}_{6}$ in acetonitrile under an argon atmosphere with excess trifluoroethanol. 


\section{Controlled Potential Electrolysis and Headspace Analysis}

Bulk electrolysis for headspace analysis were performed in a custom $\mathrm{H}$-cell equipped with a sampling port (see Fig S17) and with anode and cathode chambers separated by a fine glass frit. The working electrode chamber contained a glassy carbon plate electrode and a silver wire single junction pseudo-reference electrode. This was referenced externally vs $\mathrm{Fc} / \mathrm{Fc}^{+}$. The counter electrode chamber contained a glassy carbon plate electrode as anode or a high-surface area carbon cloth. Before electrolysis, the atmosphere in the cell was replaced with carbon dioxide and the electrolyses were run under constant potential conditions. Headspace $\mathrm{CO}_{2}$ and $\mathrm{H}_{2}$ detection was performed on a Hewlett-Packard 5890 Series II GC with a TCD detector. A Haysep D packed column Restek PC14480 cooled with ice. The analysis was performed with argon carrier gas at $20 \mathrm{~mL} / \mathrm{min}$. Samples were taken from the headspace using an gas-tight syringe in $200 \mathrm{uL}$ aliquots.

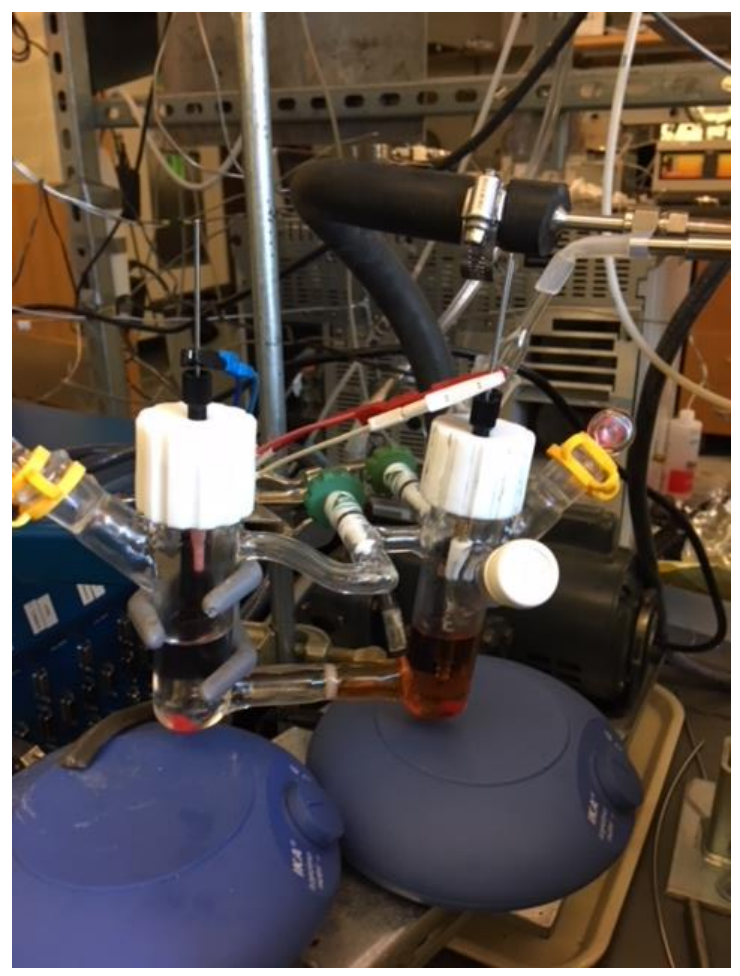

Figure S17. Electrolysis H-Cell. 


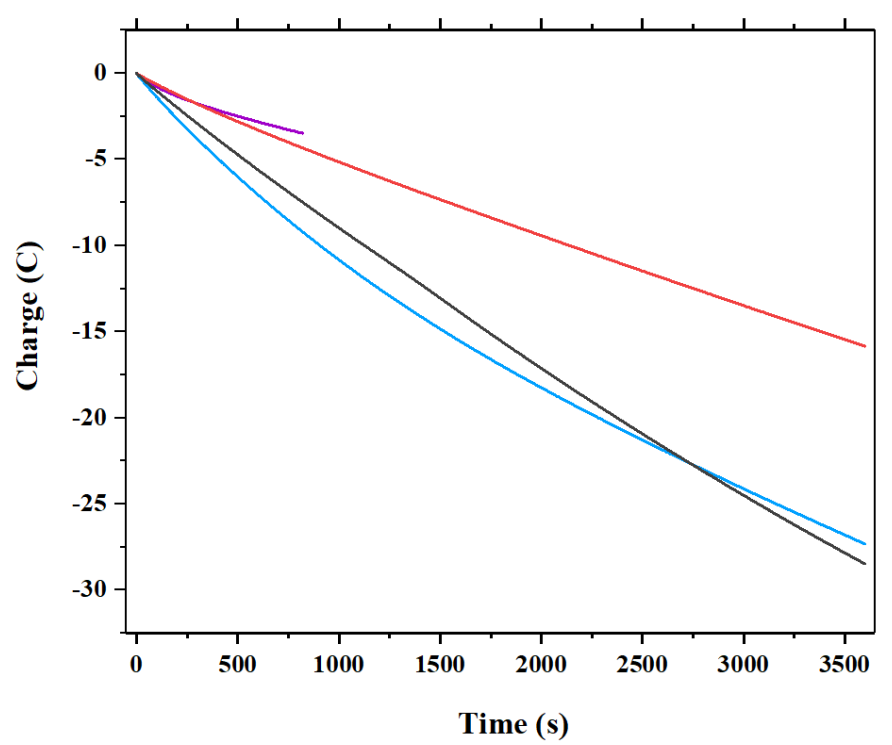

Figure S18-1. Plot of charge (C) vs. time for controlled potential electrolyses.

Electrolysis of 2 under argon to 1 eq. of electrons (purple), 2 under $\mathrm{CO}_{2}$ (red), and 2 under $\mathrm{CO}_{2}$ with added 2,2,2-trifluoroethanol (TFE) (blue), and 1 under $\mathrm{CO}_{2}$ with TFE are plotted.

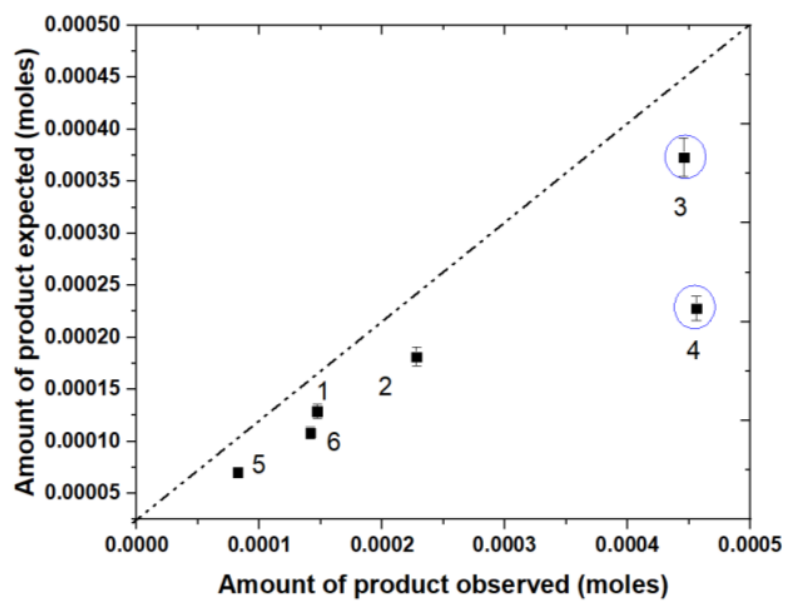

Figure S18-2. Plot of product observed over time for the table entries in Table S2. The entries circled in blue are entries for which values for $\mathrm{H}_{2}$ and $\mathrm{CO}$ were added. $\mathrm{No}_{2}$ was detected in entries 1, 2, 5 and 6 . 


\begin{tabular}{|c|c|c|c|c|c|c|c|}
\hline Entry & Catalyst & Conditions $^{\mathbf{a}}$ & $\begin{array}{c}\text { Charge } \\
\text { Passed } \\
\text { (C) }\end{array}$ & $\begin{array}{c}\text { Charge } \\
\text { Expected }^{\mathrm{b}} \\
\text { (C) } \\
\end{array}$ & $\begin{array}{c}\text { Total } \\
\text { Faradaic } \\
\text { Efficiency } \\
\end{array}$ & $\begin{array}{c}\text { TON obs } \\
\mathrm{H}_{2} / \mathrm{Cat}^{\mathrm{T}}\end{array}$ & $\begin{array}{l}\text { TON obs } \\
\text { CO/Cat }\end{array}$ \\
\hline 1 & 1 & $\begin{array}{c}-2.3 \mathrm{~V}, \text { no } \\
\mathrm{H}^{+}, \mathrm{CO}_{2}\end{array}$ & 28.4 & 24.9 & 87 & $\mathrm{n} / \mathrm{a}$ & 6.41 \\
\hline 2 & 1 & $\begin{array}{c}-2.7 \mathrm{~V}, \text { no } \\
\mathrm{H}^{+}, \mathrm{CO}_{2}\end{array}$ & 44 & 35 & 80 & $\mathrm{n} / \mathrm{a}$ & 11.1 \\
\hline 3 & 1 & $\begin{array}{l}-2.7 \mathrm{~V}, 5 \% \\
\mathrm{TFE}, \mathrm{CO}_{2} \\
\end{array}$ & 86 & 72 & 84 & 2.1 & 16.7 \\
\hline 4 & 2 & $\begin{array}{l}-2.7 \mathrm{~V}, 5 \% \\
\mathrm{TFE}, \mathrm{CO}_{2}\end{array}$ & 88 & 44 & 50 & 3.7 & 8.3 \\
\hline 5 & 2 & $\begin{array}{c}-2.3 \mathrm{~V}, \text { no } \\
\mathrm{H}^{+}, \mathrm{CO}_{2} \\
\end{array}$ & 15.9 & 13.6 & 85.8 & $\mathrm{n} / \mathrm{a}$ & 3.5 \\
\hline 6 & 2 & $\begin{array}{c}-2.3 \mathrm{~V}, \\
5 \% \mathrm{TFE}, \\
\mathrm{CO}_{2}\end{array}$ & 27.3 & 20.9 & 76 & $\mathrm{n} / \mathrm{a}$ & 5.4 \\
\hline
\end{tabular}

a Electrolyses were ran in a two-chamber custom cell with a glass frit separator with carbon working and counter electrodes in $20 \mathrm{~mL}$ MeCN $0.1 \mathrm{M} \mathrm{NBu} 4 \mathrm{PF}_{6}$ in the working chamber at $1 \mathrm{mM}$ catalyst concentration and $\mathrm{CO}_{2}$ saturation where applicable. The counter chamber was also $20 \mathrm{~mL} \mathrm{MeCN} 0.1 \mathrm{M} \mathrm{NBu}_{4} \mathrm{PF}_{6}$. The potentials reported are vs $\mathrm{Fc} / \mathrm{Fc}^{+}$and recorded against a $\mathrm{Ag}$ wire single junction reference. The channel of the multichannel BASI VMP 300 potentiostat was equipped with a $48 \mathrm{~V}$ booster to accommodate the compliance necessity of our resistive medium. b A control experiment of catalyst 2 under standard conditions, in the absence of protons at -2.3 $\mathrm{V}$ that delivered one equivalent of electron/Mn under $\mathrm{Ar}$ revealed an apparent superstoichiometric release of $\mathrm{CO}$ from the Mn complex close to 2CO/Mn. Since the experiment conducted was at a low confidence quantitation level, we subtract the observed amount to correct the expected charge passed to obtain a corrected value of faradaic efficiency. $d$ Value of turnover number is an underestimation of real turnover number during the electrolysis experiment since not all the catalyst is active at the electrode surface at once.

Table S2. Bulk Electrolysis results 


\section{Infrared Spectroscopy}

Infrared spectra were collected on a Thermo Scientific IS5 FT-IR spectrometer equipped with either $\mathrm{KBr}$ plate or a Harrick Liquid IR flow cell with a 150 micron spacer and $\mathrm{ZnSe}$ windows.

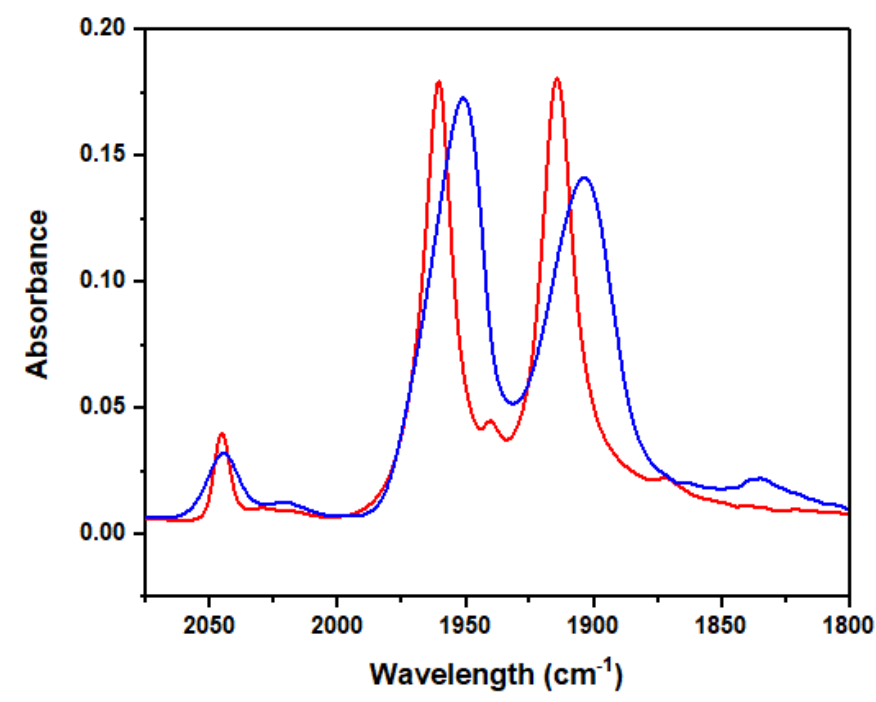

Figure S19. Infrared spectroscopy of 1 and 2, red and blue respectively, in solid phase on $\mathrm{KBr}$ Plate.

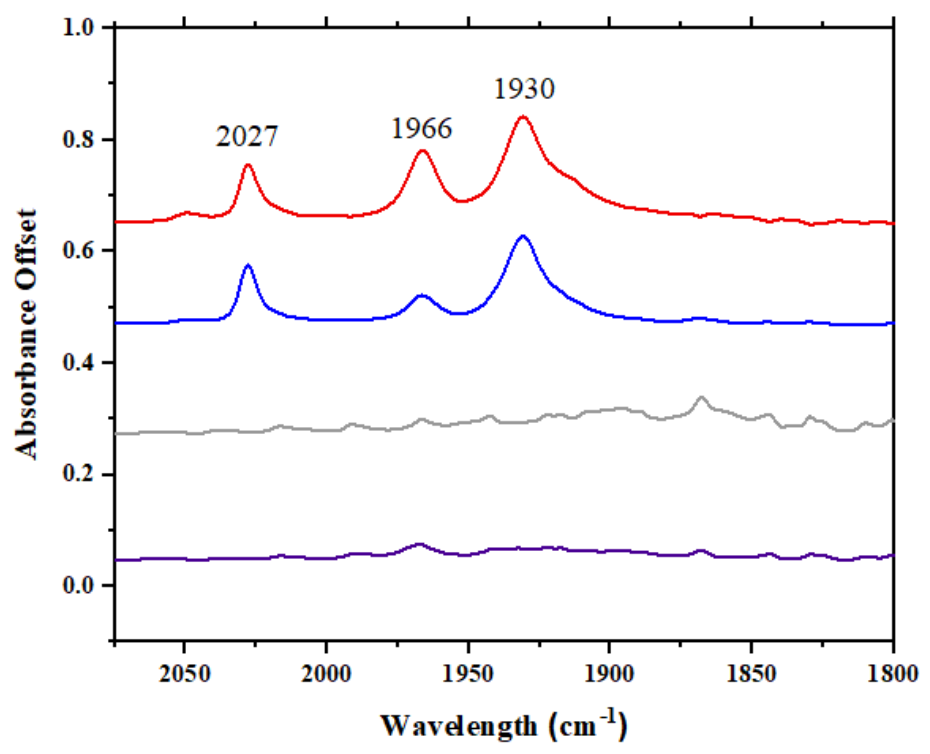

Figure S20. Liquid IR signatures of $\mathbf{1}$ (red) and $\mathbf{2}$ (blue). In grey and purple are $\mathbf{1}$ and $\mathbf{2}$, respectively, after bulk electrolysis. After application of potential had ceased, a solid precipitate began to form and had to be filtered out using a 45 micron teflon frit before the infrared spectra could be taken in the thin-film liquid Harrick Cell. 


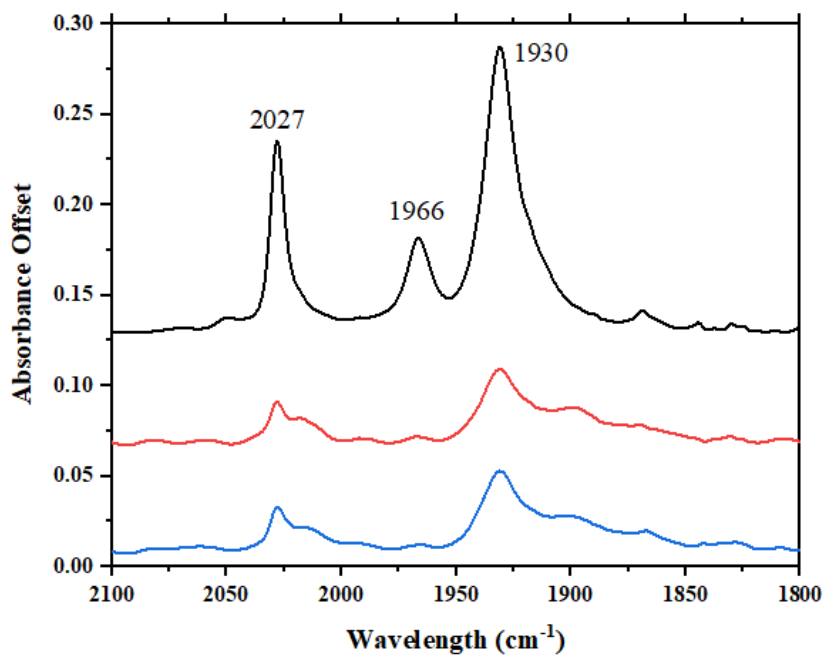

Figure S21. Infrared spectra of 2 (black), 2 after electrolysis under argon which passed 1 eq. of electrons (blue), and the same sample placed under $\mathrm{CO}_{2}$ (red). No precipitation is visibly observed during experiment. Solid precipitates upon standing.

\section{Crystal Structure Details for 1}

X-ray crystal structures were Bruker D8 Quest Eco three circle goniometer platform equipped with a Bruker APEX-II CCD detector. A graphite monochromator was employed for wavelength selection of the Mo K $\alpha$ radiation $(\lambda=0.71073 \AA)$. The data were processed using APEX III software provided by Bruker. Suitable crystals of compound 1 for X-ray diffraction were grown by layering a methylene chloride solution of $\mathbf{1}$ with pentane and allowing crystals to form at low temperature in a freezer. 


\section{Comparison of $i_{\text {cat }} / i_{\mathrm{p}}$ for 1 and 2 against several known $\mathrm{CO}_{2}$ reduction catalysts from literature values and measured in our hands for side-by-side comparison}

\begin{tabular}{ccccccc} 
Entry & Catalyst & Acid & [Acid] $(\mathbf{M})$ & $\mathbf{i}_{\text {cat }} / \mathbf{i}_{\mathbf{p}}$ & TOF $\left(\mathbf{s}^{-1}\right)$ & Reference \\
\hline $\mathbf{1}$ & $\mathrm{Mn}(\mathrm{bpy}-t \mathrm{Bu})$ & $\mathrm{H}_{2} \mathrm{O}$ & 3.1 & 25 & 120 & 1 \\
$\mathbf{2}$ & $\mathrm{Mn}(\mathrm{bpy}-t \mathrm{Bu})$ & $\mathrm{TFE}$ & 1.4 & 42 & 340 & 1 \\
$\mathbf{3}$ & $\mathrm{Re}(\mathrm{bpy}-t \mathrm{Bu})$ & $\mathrm{H}_{2} \mathrm{O}$ & 3.1 & 5.4 & 5.7 & 1 \\
$\mathbf{4}$ & $\mathrm{Re}(\mathrm{bpy}-t \mathrm{Bu})$ & $\mathrm{TFE}$ & 1.4 & 46 & 410 & 1 \\
$\mathbf{5}$ & $\mathrm{Mn} \mathrm{Mono} \mathrm{NHC}(\mathrm{Bn})$ & $\mathrm{H}_{2} \mathrm{O}$ & 2.77 & 2 & 0.08 & 2 \\
$\mathbf{6}$ & $\mathrm{Mn} \mathrm{Mono} \mathrm{NHC}(\mathrm{Im})$ & $\mathrm{H}_{2} \mathrm{O}$ & 2.77 & 1.9 & 0.07 & 2 \\
$\mathbf{7}$ & $\mathbf{1 ~ M n}(\mathrm{CNC})^{\mathrm{Me}}(\mathrm{CO})_{3} \mathrm{Br}$ & $\mathrm{TFE}$ & 0.0373 & 37.14 & 267.5 & This work \\
$\mathbf{8}$ & $\mathbf{2 ~ M n}(\mathrm{CNC})^{\mathrm{Bn}}(\mathrm{CO})_{3} \mathrm{Br}$ & $\mathrm{TFE}$ & 0.0373 & 25.72 & 128.3 & This work \\
$\mathbf{9}$ & $\mathrm{MnBr}(\mathrm{HOPh}-\mathrm{bpy})(\mathrm{CO})_{3}$ & $\mathrm{H}_{2} \mathrm{O}$ & 2.77 & $10.9^{*}$ & 23.0 & 3 \\
$\mathbf{1 0}$ & $\mathrm{Ni}(\mathrm{CNC})^{\mathrm{Bn}}$ & $\mathrm{H}_{2} \mathrm{O}$ & 1.1 & 5.7 & 0.63 & 4
\end{tabular}

${ }^{*} i_{\text {cat }} / i_{p}$ values for Entries 1-8 taken at peak current, but $i_{\text {cat }} / i_{p}$ value was taken at $E_{p}$ (the voltage at half the catalytic maximum)

Table S3-1 $\mathrm{i}_{\text {cat }} / \mathrm{i}_{\mathrm{p}}$ analyses and observed turnover frequencies for several literature compounds compared to $\mathbf{1}$ and $\mathbf{2}$. Reference details shown below.

References:

1. DOI: $10.1021 / \mathrm{ic} 302391 \mathrm{u}$

2. DOI:10.1002/anie.201311099

3. DOI: $10.1021 /$ acs.inorgchem.5b00233

4. DOI: $10.1039 / C 5 D T 02916 C$

\begin{tabular}{cccccc} 
Entry & Catalyst & Acid & {$[$ Acid] $\mathbf{( M )}$} & $\mathbf{i}_{\mathbf{c a t}} / \mathbf{i}_{\mathbf{p}} \mathbf{a}^{\mathbf{a}}$ & TOF $\left(\mathbf{s}^{-\mathbf{1}}\right)^{\mathbf{b}}$ \\
\hline $\mathbf{1}$ & $\mathbf{1}^{\mathrm{Me}} \mathrm{Mn}(\mathrm{CNC})^{\mathrm{Me}}(\mathrm{CO})_{3} \mathrm{Br}$ & $\mathrm{TFE}$ & 0.229 & 34.97 & 237.1 \\
$\mathbf{2}$ & $\mathbf{2}^{\mathrm{Bn}} \mathrm{Mn}(\mathrm{CNC})^{\mathrm{Bn}}(\mathrm{CO})_{3} \mathrm{Br}$ & $\mathrm{TFE}$ & 0.229 & 22.35 & 96.9 \\
$\mathbf{3}$ & $\mathrm{Mn}(\mathrm{bpy})(\mathrm{CO})_{3} \mathrm{Br}$ & $\mathrm{TFE}$ & 0.229 & 4.13 & 3.30 \\
$\mathbf{4}$ & $\mathrm{Mn}\left({ }^{{ } \mathrm{Bu} b p y)}\right.$ & $\mathrm{TFE}$ & 0.229 & 7.37 & 10.5 \\
$\mathbf{5}$ & $\mathrm{Re}(\mathrm{bpy})(\mathrm{CO})_{3} \mathrm{Cl}$ & $\mathrm{TFE}$ & 0.229 & 10.0 & 19.4 \\
\hline
\end{tabular}

Table S3-2. Catalytic turnover frequencies side-by-side comparison of a $\mathbf{1}^{\mathrm{Me}}$ and $\mathbf{1}^{\mathbf{B n}}$ at $298 \mathrm{~K}$ and $1 \mathrm{mM}$ in $\mathrm{MeCN} 0.1 \mathrm{NBu}_{4} \mathrm{PF}_{6}$ measured in our lab. ${ }^{b_{c a t}} / \mathbf{i}_{\mathrm{p}}$ values taken at peak values and calculated using the literature-established procedure. 